\title{
Judicial Right Declaration and Entrenched Discrimination
}

"[W]here there is a legal right, there is also a legal remedy." This axiom generates an expectation that a court deliver a prompt remedy that matches the articulated right. The virtue of this right-remedy obligation is clear: By proceeding from an independent articulation of a right or violation to considerations for providing an adequate remedy, courts perform not as choirs ${ }^{2}$ but instead as instruments of right-actualization.

The virtue of this matching, or unified, approach is open to question, however, where remedial considerations are the primary source of conflict and disagreement. ${ }^{3}$ In constitutional cases involving entrenched discrimination, for example, ${ }^{4}$ controversial remedial costs often result from, and increase with, the severity both of past discrimination and of the governmental, judicial, and societal neglect in remedying the continuing effects of prior discrimination. In these cases, a perceived obligation to deliver a

1. See W. Blackstone, Commentaries on the Laws of England *22 ("[I]t is a general and indisputable rule, that where there is a legal right, there is also a legal remedy, by suit or action of law, whenever the right is invaded."); see also United States v. Louisiana, 380 U.S. 145, 156 (1964) (Black, J.) (stressing "[t]he need to eradicate past evil effects and to prevent the continuation or repetition in the future of the discriminatory practices shown to be so deeply engrained in the laws, policies and traditions").

2. See A. Bickei, The Least Dangerous Branch 246-47 (1962).

3. Abram Chayes has cogently analyzed how the relief in public law adjudication departs from the relief in traditional adjudication, which imposes particularized remedies on the basis of individual liability. Chayes, The Role of the Judge in Public Law Litigation, 89 Harv. L. Rev. 1281 (1976). Chayes asserts that in many of the most important legal disputes in a complex society, judges must consider the relevant social environment if they are to provide remedial justice. In a prominent essay on constitutional values and structural reform, Professor Fiss discusses challenges facing the judge in complex public adjudication. See Fiss, The Supreme Court, 1978 Term-Foreword: The Forms of Justice, 93 Harv. L. REv. 1 (1979). Fiss contends that as the quality of modern life is greatly affected by large-scale bureaucratic institutions, the extent to which constitutional values play a role in our lives will be contingent on the success of judges in implementing such values in large institutional structures. Id. at 2-8. Fiss concedes that this will often be a trying task for judges, and may even threaten judicial independence. Nonetheless, argues Fiss, this "core dilemma" must be confronted if courts are to play their intended roles in protecting constitutional rights. Id. at 51-58.

This Note does not seek to enter the debate concerning judicial competence to implement complex structural remedies. Compare O. FIss, The Crvil RIGHTS INJunction (1978) and Note, Judicial Intervention and Organization Theory: Changing Bureaucratic Behavior and Policy, 89 YALE L.J. 513 (1980) with Glazer, Should Judges Administer Social Services?, 50 PuB. INTEREST 64 (1978) (contending that judges lack competence to fashion complex social remedies). Instead, this Note seeks to explore both the extent to which agreement on rights is possible where consideration of rights and remedies is bifurcated, and the long-term effect such an articulation of rights might have in achieving corrective justice in public law cases.

4. See, e.g., Milliken v. Bradley, 418 U.S. 717 (1974) (Detroit school desegregation case); Swann v. Charlotte-Mecklenberg, 402 U.S. 1 (1971) (Charlotte); United States v. Board of Educ. of Chicago, 744 F.2d 1300 (7th Cir. 1984) (Chicago); Morgan v. Kerrigan, 509 F.2d 580 (1st Cir. 1974), cert. denied, 421 U.S. 963 (1975) (Boston); Hobsen v. Hansen, 269 F. Supp. 401 (D.D.C. 1967), affd sub nom. Smuck v. Hobson, 408 F.2d 175 (D.C. Cir. 1969) (Washington, D.C.). 
unified opinion can easily result in remedial factors exerting a backward influence that restricts the scope of articulated rights. To allow such remedial considerations to trim rights is to allow the depth of past wrongs and majoritarian hositility or unwillingness to bear remedial costs to be instrumental in narrowing present and future rights. Whatever the merits of contemplating such factors when devising relief, neither majority hostility nor the severity of unremedied harm are appropriate considerations for contracting the contours of minority rights. Because the core conflict in cases of entrenched discrimination often involves remedial considerations that are not appropriate to the formation of rights, this Note argues that judges should conceptually and procedurally bifurcate their determination of right and remedy to ensure the independent declaration of minority rights. ${ }^{8}$

Bifurcation neither condones inadequate remedies nor guarantees full remedies. Bifurcation simply requires that controversy over remedial costs or judicial competence not obstruct the articulation of the full right at stake, $^{7}$ Although gaps between rights declared and remedies imposed can

5. The controversy over judicial desegregation orders cannot be seen totally as an issue of judicial competence. Where massive resistance has been absent, courts have in the past used their equity powers for far more complex matters. For example, around the turn of the century, "nearly 25 percent of the entire railroad system of the country ha[d] been in receivership, the receivers becoming virtually operators of this large fraction of the transportation system. Since 1870 there [had been] over one thousand railroad receiverships." Berle, Receivership, in 13 ENCYClopedia of THE Social ScIENCES 149 (1934).

6. The process of conceptual bifurcation advocated in this Note in no way alters established "case or controversy" or justiciability doctrine. Cases of entrenched discrimination have in fact been distinguished by both their controversial and their adversarial nature. See Gewirtz, Remedies and Resistance, 92 YALE L.J. 585 (1983) (discussing history of resistance to school desegregation decrees). Difficult desegregation cases always involve analyzing and resolving the specific facts of a dispute and not "opinion[s] advising what the law would be upon a hypothetical state of facts." Aetna Life Ins. Co. v. Haworth, 300 U.S. 227, 241 (1936). The Supreme Court has in fact, several times, been willing to declare rights even though the capability for remedial enforcement was questionable. See Powell v. McCormick, 395 U.S. 486, 548-49 (1969) (bifurcating and deferring consideration of whether or not coercive judicial relief was possible and issuing declaratory judgment invalidating exclusion of Congressman Powell); Glidden Co. v. Zdanok, 370 U.S. 530, 570-71 (1962) (Harlan, J.) (inability of Court of Claims and Court of Customs and Patent Appeals to enforce remedies against the federal government "does not debar those courts from exercising the judicial power provided for in Article III"); South Dakota v. North Carolina, 192 U.S. 286, 318-21 (1904) (rendering decision in suit for money between states, despite judicial impotence to enforce the award). See generally J. Nowak, R. Rotunda \& J. Young, Constrtutional Law 112-13 (2d ed. 1983). Furthermore, the Supreme Court's approval of the Declaratory Judgment Act further supports the view that coercive relief by the judiciary is not determinative of justiciability under Article III. See Aetna Life Insurance Co. v. Haworth, 300 U.S. 227 (1936). The fact that bifurcation may allow courts to declare rights broader than they themselves can, or will, enforce does not relieve other governmental parties from an obligation to close the gap. See infra note 83 .

7. It is important to distinguish between support for the process of bifurcation and the substantive result of a particular remedial decision. For example, one could disapprove of the remedial balancing in Brown v. Board of Educ., 349 U.S. 294 (1955) (Brown II) (remedial decision permitting deliberate speed), while still supporting the decision to bifurcate because it may have prevented the Court's differences over remedies from obstructing their declaration of the right to be free from the effects of state-imposed caste distinctions. Brown v. Board of Educ., 347 U.S. 483 (1954) (Brown $I$ ) (unanimous 
exist under such an approach, the clear declaration of rights forces the majority to confront $t^{8}$ the right-reality discrepancy and provides minorities with a unifying claim to press for future judicial or majoritarian remedies.

\section{Matching Remedies to Rights: Brown to Swann}

The declaration in Brown $I,{ }^{9}$ that state-maintained school segregation is unconstitutional, instantaneously created a wide discrepancy between constitutional ideals and reality for black school children. In the years between Brown and Swann v. Charlotte-Mecklenberg, ${ }^{10}$ this disturbing gap prompted civil rights advocates to push continually for judicial remedies that would truly realize the rights articulated in Brown $I$.

Brown ushered in a period of remedial crises. A decade after the decision only $1.2 \%$ of black children in the South were attending schools with any whites. ${ }^{11}$ From a pure private-law perspective, in which a judicially declared right is worth its weight only in judicially enforced remedies, the right declared in Brown $I$ was meaningless.

Despite the failure of Brown $I I^{12}$ to command effective relief in the "worst-remedy"13 case of nationwide school desegregation, the right declared in Brown I was the legal basis for victory in landmark Supreme Court per curiam decisions outlawing segregation in city park facilities, ${ }^{14}$

decision on right); see Ulmer, Earl Warren and the Brown Decision, 33 J. PoL. 689, 697-78 (1971) (Chief Justice Warren tried first to discuss the decree, but was only able to get unanimity when the Justices agreed to decide the right and to defer consideration of the remedy).

Bifurcation, in fact, allows plaintiffs greater room to plead responsibly for broad remedies. Once the court declares the right, plaintiffs do not have to fear that pleas for broad matching relief will scare the court into narrowing the definition of the right or violation.

8. Conversely, denying the existence of a full right can legitimate a constitutionally distateful condition. See Wright, The Role of the Supreme Court in a Democratic Society-Judicial Activism or Restraint?, 54 CoRnelL L. REv. 1, 7 (1968):

As Professor Black has perceptively observed ... . when the Court upholds a statute's constitutionality it "legitimates" it. When a statute expresses the most enlightened sentiments of the community, this legitimating function may serve [an] important and creative purpose .... But unfortunately the Court's seal of constitutional approval has the same effect where the statute is a repressive one.

9. 347 U.S. 483 (1954).

10. 402 U.S. 1 (1970).

11. U.S. Comm'n on Crvil Rights, Fulfilling the LetTer and Spirit of the Law: DeSEgRegation OF THE NATION's PUBLic Schools 6 (1976). As of August 1, 1963, there was not a single desegregated school district in all of Alabama, Mississippi and South Carolina, and only one in Louisiana and Georgia. See H.R. REP. 914, 88th Cong., 2d Sess., reprinted in 1964 U.S. CoDE Cong. \& AD. NEWS 2391, 2504-06.

12. 349 U.S. 267 (1955).

13. This Note uses the term "worst-remedy" to refer to cases in which the actualization of a declared right would force the court to confront extreme political and social resistance. Even where remedial concerns are appropriate for defining a right in such worst-remedy cases, the danger exists that courts may narrow the general interpretation of the right, which will apply in cases where the remedial problems do not exist, or where they are inappropriate to the claim of right at stake. A perceived obligation to match right and remedy can thus encourage worst-remedy cases to have a disproportionate influence on rights. This is a variation of the maxim, hard cases make bad law.

14. Muir v. Louisville Park Theatrical Ass'n, 347 U.S. 971 (1954). 
public beaches and bath houses, ${ }^{16}$ municipal golf courses,${ }^{16}$ public transportation, ${ }^{17}$ public athletic contests, ${ }^{18}$ airport restaurants, ${ }^{19}$ and courtroom seating. ${ }^{20}$ The right-declaration in Brown $I$ enabled the NAACP Legal Defense Fund successfully to challenge post-Brown district court cases like Lonesome v. Maxwell"1 that had initially upheld the "separate but equal" principle in non-education cases.

The full force of the Brown I right-declaration, however, lay in its interaction and interdependence with the political process. Gayle v. Brow$d_{e}{ }^{22}$ provides a poignant example. The case arose from Rosa Park's refusal to yield her front-of-the-bus seat on December 5, 1955 and Martin Luther King, Jr.'s subsequent organizing of the nine-month Montgomery bus boycott. ${ }^{23}$ This incident was most crucial to the non-violent civil rights movement. ${ }^{24}$ On November 13, 1956, Dr. King declared victory, announcing to a packed church that the Supreme Court (citing Brown), had found segregated public buses unconstitutional. ${ }^{25}$ In examining this victory, one

15. Mayor of Baltimore v. Dawson, 350 U.S. 877 (1955).

16. New Orleans City Park v. Dretage, 358 U.S. 54 (1958); Holmes v. City of Atlanta, 350 U.S. 879 (1955).

17. Gayle v. Browder, 352 U.S. 903 (1956).

18. State Athletic Comm'n v. Dorsey, 359 U.S. 533 (1959).

19. Turner v. City of Memphis, 369 U.S. 350 (1962).

20. Johnson v. Virginia, 373 U.S. 61 (1963).

21. 123 F. Supp. 193 (D. Md. 1954), rev'd sub nom. Dawson v. Mayor of Baltimore, 220 F.2d 386 (4th Cir.), affd, 350 U.S. 877 (1955) (per curiam).

22. 352 U.S. 903 (1956). Gayle v. Browder shows that even within two years the right declared in Brown $I$ had gained force. At the district level, where a three-judge court had ruled in favor of plaintiffs, Judge Seyborn H. Lynne dissented, declaring that "[o]nly a profound, philosophical disagreement" and his "study of Brown . . . convinced [him] that it left unimpaired the 'separate but equal' doctrine in ... local transportation." 142 F. Supp. 707, 717, 719-20 (M.D. Ala. 1956) (Lynne, J., dissenting). Judge Lynne's dissent, as well as the Montgomery Board of Commissioner's brief before the Supreme Court, argued that the Court's statement in Plessy v. Ferguson had involved "not education but transportation." Brown I, 347 U.S. at 491; see Appellant's Jurisdictional Statement at 17, Gayle v. Browder, 352 U.S. 903 (1956). Judge Rive's opinion, however, stressed that Brown, in conjunction with Mayor of Baltimore v. Dawson, 350 U.S. 877 (1955), and Holmes v. Atlanta, 350 U.S. 879 (1955), had established a broader anti-caste or anti-segregation principle. 142 F. Supp. at 716-17. The Supreme Court obviously agreed; it affirmed per curiam, citing Brown, Dawson and Holmes. The crucial point is that the remedial failures in Brown did not limit Brown's power in changing the general interpretation of the Fourteenth Amendment and, thus, in actualizing those rights in cases with less controversial remedies.

23. See generally M. KInG, Stride Towards Freedom (1962) (King's own account of Montgomery bus boycott).

24. See M. King, Where Do We Go From Here: Chaos or Community? 17 (1967) (Montgomery bus boycott "inspired and informed far-flung movements that included sit-ins, boycotts and mass marches . . . a new method of protest action had been born."); L. BENNETT, CoNFronTation: BLACK AND WhITE 11 (1966) ("Montgomery and Martin Luther King, Jr., created a revolutionary point of departure which the sit-in students carried to a new stage of development."); P. CARROLL \& D. Noble, The Free and THE UNFree 406-07 (1977) ("From Montgomery, protests spread throughout black communities. All aspects of Jim Crow caste patterns were being challenged.").

25. See J. Bass, UnLikely Heroes 76 (1981) (after the favorable Supreme Court decision, "King called a mass meeting and ten thousand Negros jammed two of Montgomery's largest black churches and the adjacent streets."). 
must ask not whether political protest or the Supreme Court was the determinative factor. The story can be told only in their positive interaction.

Whereas Plessy $v$. Ferguson ${ }^{26}$ had frozen the anti-caste claims of blacks, Brown fanned an already-sparked fire ${ }^{27}$ by placing the legal and moral weight of the Constitution behind the black leadership who sought to dismantle the southern caste system. More important than Brown II's specific remedy was the tension of a highly visible gap between constitutional rights and judicial remedies that fueled the political process. Massive resistance to judicial decrees forced white America to confront racism openly, ${ }^{28}$ while allowing blacks to unify on several fronts behind the claim of an unkept constitutional promise. ${ }^{28}$ Throughout the movement, Martin Luther King sought to stir national dissonance by invoking the image of the right-reality gap in American race relations. ${ }^{30}$ Eventually the political

\section{163 U.S. 537 (1896).}

27. Major chroniclers of this period have recognized Brown as crucial in spurring the civil rights movement. See R. KLUGER, Simple Justice 749 (1975) ("The mass movement sparked by Brown was unmistakably thriving as soon as six months after the Court handed down its implementation decree"); see also J. WILKInSON, From BROWN To BAKKE 49 (1979) ("Brown was the catalyst that .. . culminated in the two major Civil Rights acts.").

28. The role that the media plays in publicizing Court decisions and the social protests over rightremedy gaps will often be crucial. This was particularly true in the Birmingham, Alabama protests of 1963. See Bickel, After a Civil Rights Act, THE NEw Republic, May 9, 1964, at 11-15 (after nation watched beating of protestors in Birmingham, a "new climate of national opinion was created on the streets of Birmingham."); see also D. Ravitch, The Troubled Crusade: AMErican Education 1945-1980, at 139 (1983) ("It seemed outrageous to the distant television viewer to see white men striking blacks who were not resisting blows, in order to prevent the blacks from ordering a cup of coffee or from sitting where they wished in a bus terminal."); M. KING, WHY WE CAN'T WAIT (1964) (King's account of Birmingham protests).

29. Though they pressed for strong and immediate relief from the Court, plaintiffs attorneys in Brown, Thurgood Marshall and Robert Carter, believed that the positive impact of Brown would come largely from the political action that the right-declaration encouraged. See Carter \& Marshall, The Meaning and Significance of the Supreme Court Decree, 24 J. NEgRo Educ. 397, 402-03 (1955):

The [Brown] decision opened the door for Negroes to secure unsegregated educational facilities if they do so desire. . . [L]ittle will be done for the most part unless Negroes demand and insist upon desegregation ... [I]t will be accomplished only after a long and bitter fight, the brunt of which will become a reality only if Negroes exhibit real militancy and press relentlessly for their rights.

30. See M. KING, supra note 24 , at 10-11:

School desegregation is still 90 percent unimplemented across the land . . . Thus America, with segregationist obstruction and majority indifference, silently nibbled away at a promise of true equality that had come before its time ... . [F]or the Negro there is a credibility gap he cannot overlook.

At crucial points near the end of his life, President John F. Kennedy also forced the public to confront the discrepancy between American ideals and the plight of black Americans:

If an American, because his skin is dark . . . cannot send his children to the best public school available... . [A]re we to say to the world-and much more importantly to each other-that this is the land of the free, except for the Negroes; that we have no second-class citizens, except Negroes; that we have no class or caste system, no ghettos, no master race, except with respect to Negroes?

Television Address by President Kennedy, quoted in R. KLUGER, supra note 27, at 756. 
process responded, ${ }^{31}$ and enacted the Civil Rights Act of $1964,{ }^{32}$ the Voting Rights Act of $1965,{ }^{33}$ and the Fair Housing Act of $1968 .^{34}$

Moreover, the interaction between the judicial and political branches was dialectical and mutually supportive. ${ }^{35}$ While right declaration inspired majoritarian backing of antidiscrimination enforcement, such popular, ${ }^{36}$ legislative, ${ }^{37}$ and executive ${ }^{38}$ support in turn gave the "least dangerous branch"39 the confidence that their bold remedial decrees would ultimately be enforced. By the end of the 1960's, the Court had commanded school boards to eliminate segregation "root and branch,"40

31. Two years after Brown, sixty civil rights bills were given congressional hearings, resulting in the 1957 Civil Rights Act, Pub. L. No. 85-315, 71 Stat. 634 (1957); see Dep't of Justice, Office of Att'y Gen., Order No. 155-57 (Dec. 9, 1957) (establishing Civil Rights Division). While the Act authorized the federal government to obtain injunctions only in voting rights cases, it helped lay the administrative framework for serious civil rights enforcement by the federal government.

In 1960 , both national political parties committed themselves in their party platforms to a program that would eliminate discrimination and encourage equal opportunity. These statements were prominently cited in the legislative history of the Civil Rights Act of 1964. See S. REP. No. 872, supra note 10, at 2362-63:

As to those matters within reach of political action and leadership, . . . We pledge the full use of the power, resources, and leadership of the Federal Government to eliminate discrimination based on race, color, religion, or national origin . . . . ("Building a Better American," Republican platform, 1960).

The peaceful demonstrations for first-class citizenship . . . are a signal to all of us to make good at long last the guarantees of our Constitution .... The time has come to assure equal access . . to all areas of community life. . . ("The Rights of Man," Democratic platform, 1960).

At many other prominent places in the legislative history of the Civil Rights Act of 1964, the need for legislation to close the right-remedy gap is stressed. See id. at 2504 ("[T]he constitutional right to be free from racial discrimination in public education must be realized."); see also id., at 2368-77, 2393-94, 2410-12, 2503-19.

32. Pub. L. No. 88-352, 78 Stat. 241 (1964) (codified as amended at 42 U.S.C. $§ 2000 \mathrm{a}-2000 \mathrm{~h}$ (1976 \& Supp. V 1981)).

33. Pub. L. No. $89-110,79$ Stat. 437 (1965) (codified as amended at 42 U.S.C. $\$ \S 1971$, 1973-1973dd (1976 \& West Supp. 1983).

34. Pub. L. No. $90-284,82$ Stat. 73 (codified as amended at 42 U.S.C. $\$ \S 3601-3619,3631$ (1976)).

35. See M. King, The Words of Martin Luther King, JR. 57 (1983):

Direct action is not a substitute for work in the courts and the halls of government. Bringing about passage of a new and broad law . . . does not eliminate the necessity for bringing about the mass dramatization of injustice in front of a city hall. Indeed, direct action and legal action complement one another; when skillfully employed, each becomes more effective.

36. In $1959,83 \%$ of parents in the south objected to their children attending a school that was half-integrated. By 1970 , only $43 \%$ objected to equally-integrated schools, while during the same time span those parents objecting to marginal integration declined from $72 \%$ in 1959 to $16 \%$ in 1970,3 The Gallup Poll: Public OpINION 1935-1971, at 1598, 2010, 2211 (1972), reprinted in G. Orfield, Must We Bus? 109 (1978).

37. See supra notes $31-34$.

38. For an account of the role of Burke Marshall, Assistant Attorney General, Civil Rights Division and other Justice Department lawyers in using executive enforcement, see J. BAss, supra note 25, at 306-07 (1981) (Justice Department intervention in crucial Jefferson County Alabama case); V. NAVASKY, KenNEDY Justice 96-155 (1971).

39. See A. Bickel, supra note 2 .

40. See Green v. County School Bd., 391 U.S. 430, 437-38 (1969) (district must convert to plan that eliminated discrimination "root and branch"). 
though it still had not authoratively defined the remedial obligations of school authorities and district courts in implementing Brown I.

\section{Post-Swann: Denying a Right-Remedy GaP}

Unlike the major southern cases of the 1950's and 1960's, cases involving racially identifiable schools in northern urban centers did not also involve a facially unconstitutional statute. ${ }^{11}$ Thus, northern cases demanded a vital step unnecessary in adjudicating southern school segregation-the plaintiff had to establish a violation itself. This required a complex inquiry. School segregation in many northern cities resulted directly from residential racial containment ${ }^{\mathbf{4 2}}$ in the inner core of those cities. While local school board policies had often contributed substantially to this condition, such residential segregation was inevitably the result of a network of state policies. ${ }^{43}$

Swann v. Charlotte-Mecklenberg was a pivotal point in school segregation cases. ${ }^{44}$ On one hand, Swann was typical of the southern de jure case

41. See Morgan v. Kerrigan, 509 F.2d 580, 582 n.1 (1st Cir. 1974) (citing twelve cases in western and "northern cities where segregation had often resulted from local practices rather than laws."); see also J. WILkInson, supra note 27, at 55 ("The North had its own way of distancing the Negro, all without segregation statutes. In the North, the barrier was housing, potentially the most effective of all.").

42. The term "racial containment" refers to the process whereby public and private discrimination in housing, investment, and educational policies gradually concentrates minorities in the center core of cities. Plaintiffs in Milliken v. Bradley used the terms "containment" and "confinement" interchangeably in oral argument before the Supreme Court:

[A] series of mutually supportive, interlocking [governmental] devices, . . . especially the segregated school practices, operated in lockstep with an areawide metropolitan policy of confining by housing discrimination at the local level, at the governmental levels, both state and federal ... confining black families to an identifiable core . . expanding, but still surrounded by a white ring of reciprocal corresponding schools.

Transcript of Oral Argument, Milliken v. Bradley, 418 U.S. 717 (1974), reprinted in 80 LANDMARK Briefs and Oral Arguments 1223 (1980). (P. Kurland \& G. Casper eds. 1977.)

43. Because of the state action requirement, the relevant inquiry is into the degree various governmental actions caused, fostered, or encouraged racial isolation. See J. KusHNER, APARTHEID IN AMERICA 30-52, 56-63, 86-91 (1980) (documenting discriminatory impacts of Federal Housing Administration and Veterans Administration policies as well as local zoning policies); G. MYRDAL, AN AMERICAN Dilemma 605-39 (1944) (discussing combination of governmental practices and customs fostering residential segregation); U.S. COMM'N on Crvil RIGKTS, TwENTY YEARS AFTER Brown: Equal OPPORTUNITY IN Housing 3-13, 167-68 (1975) (discussing governmental influence in racial covenants and residential segregation). For district court findings of state discrimination in school desegregation cases, see infra notes $46,53,68,69$.

44. See Columbus Board of Educ. v. Penick, 443 U.S. 449, 486 n.6 (1978) (Powell, J., dissenting):

During [1954-1964,] the issues confronted by the courts by and large involved combating the devices by which States deliberately perpetuated dual school systems and dismantled segregated systems in small, rural areas . . . This Court did not begin to face the difficult adminstrative and social problems associated with de facto segregation in large urban school systems until Swann v. Charlotte-Mecklenberg ... .

See also Brest, The Supreme Court, 1975 Term-Foreword: In Defense of the Antidiscrimination Principle, 90 Harv. L. REv. 1, 33 (1976) ("In Green the causal connection between past discrimination and the current racial composition of the schools was as clear as such matters ever can be. . . . 
in which segregation occurred by state law. On the other hand, Swann provoked newer questions critical to northern cases concerning the proof, intent, and causal impact of non-statutory state action and the constitutionality of segregated schools resulting from neighborhood assignments in residentially segregated neighborhoods. ${ }^{46}$

In the district court opinion, Judge McMillan found that a panoply of state action-ranging from city planning and real estate zoning laws to federal and state urban-renewal plans-had interwoven with and guided private discrimination to cause residential segregation in Charlotte. ${ }^{18}$ When reviewing Judge McMillan's findings, however, the Supreme Court was also aware of growing opposition to court-ordered desegregation. ${ }^{47}$ The Court may have concluded that to affirm such a wide-ranging violation along with a judicial obligation to provide immediately a matching remedy would give ambitious district court judges an overly-

In this respect, Green was the Court's last easy school desegregation case.").

45. Many scholars and judges have defined the violation at stake in Brown $I$ as the state-fostered or maintained caste status of an identifiable sub-group. For the most comprehensive presentation of this theory, see Dimond, The Anti-Caste Principle-Toward a Constitutional Standard for Review of Race Cases, 30 WAYNE L. REv. 1, 42-61 (1983) (inner city ghettoization caused by variety of state policies that should be remedied by variety of state policies); see also Williams v. City of New Orleans, 729 F.2d 1554, 1573 \& n.7 (5th Cir. 1984) (Wisdom, J., concurring in part and dissenting in part) (approving Dimond's anti-caste principle in defining systematic discrimination by New Orleans Police Department); $c f$. Keyes v. School Dist. No. 1, 413 U.S. 189, 217 (1972) (Douglas, J., concurring) ("A] State is barred from creating by one device or another ghettoes that determine the school one is compelled to attend."); Jones v. Mayer, 392 U.S. 409, 442-43 (1968) (Stewart, J.)) ("IW]hen racial discrimination herds men into ghettos and makes their ability to buy property turn on the color of their skin, then it too is a relic of slavery.").

Variations of an anti-caste principle were first delivered in three prominent law review articles defending the holding in Brown. See Black, The Lawfulness of the Segregation Decisions, 64 YALE L.J. 421, 425 (1960); Cahn, Jurisprudence, 30 N.Y.U. L. REv. 150, 161 (1955); Pollak, Racial Discrimination and Judicial Integrity: A Reply to Professor Wechsler, 108 U. PA. L. REv. 1, 28 (1959).

46. Swann v. Charlotte-Mecklenberg, 300 F. Supp. 1358 (W.D.N.C.), 306 F. Supp. 1299 (W.D.N.C. 1969), affd in part and vacated in part, 431 F.2d 138 (4th Gir. 1970), affd in part and vacated in part, 402 U.S. 1 (1971). In Charlotte, blacks had "become concentrated almost entirely in one quadrant of a city of 270,000 ." $300 \mathrm{~F}$. Supp. at 1360 . In order to impose affirmative duties on the school board, Judge McMillan had to establish a causal relationship between the state and the residential segregation. Instead of relying solely on the segregation law or the acts of the school board in establishing the violation, McMillan traced the role state policies had played since 1900 in causing residential segregation. Id. at 1365.

47. See G. ORFIELD, supra note 36, at 109-12. Richard Nixon ran an anti-busing campaign in 1972. Id. at 335-40. On March 16,1972, Nixon asked Congress in a nationally televised speech to enact legislation stripping much of the courts' desegregation powers. Id. at 335. On June 23, 1972, Congress did in fact pass anti-busing legislation, the Education Amendments of 1972, Pub. L. 92-318, 86 Stat. 235 , codified at 20 U.S.C. $\$ \S 1651-56$ (1982). The bill was interpreted, however, as applicable only where no constitutional violation had been found. See 2 N. DORSEN, P. BENDER, B. Neuborne \& S. Law, Polmtical and Civil Rights in the United States 693-94 (4th ed. 1979).

Polls in 1965 "showed that people saw action against discrimination as the most important question before the country . . . . During the early 1970s, the public seemed less and less concerned." See G. ORFIELD, supra, at 110 . The public ranked black problems as 24 th out of 27 th in 1972 , and last out of 30 th in 1974 , in polls ranking national priorities. Id. 
controversial blank check to restructure a wide range of state and local governmental policies. ${ }^{48}$

Swann can be understood as an attempt to resolve these right-remedy matching tensions. By authorizing broad and immediate judicial power to remedy proven constitutional violations, the Supreme Court could claim it was at last closing the remedial gap left by Brown II. At the same time, however, by limiting its violation inquiry to the actions of local school authorities and deliberately ignoring "the myriad factors ... [that] . . . can cause discrimination in a multitude of ways," ${ }^{\prime 48}$ the Court foreclosed the potential for broad state-wide intervention and for judicial consideration of the segregative effects of a network of state policies.

But why the focus only on school boards? Brown v. Board of Education had only centered the remedial focus on school boards. In the four cases joined in Brown, state statutes had been the direct source of the violation..$^{\text {.0 }}$ A subtle, yet influential, form of judicial activism occurred in Swann when the Court explicitly chose not to reach the issue of whether "other types of state action, without any discriminatory action by the school authorities, is a constitutional violation requiring remedial action by a school desegregation decree."

48. During oral arguments in Swann, the Court specifically asked Solicitor General Ervin Griswold "are we talking about the substantive right . . . or . . . the appropriate remedy. . .? They are different are they not?" Griswold replied, "Yes, Mr. Justice, but they are intertwined." The Court again pressed whether there was a difference between the "substantive constitutional right that each individual public school student has . . . [and] what is required of a court to disestablish . . . . They are interrelated, but they are also different." Griswold conceded they "are different questions," but found it "difficult to contend that if the right was established that the remedy could not be devised to protect the right." The inquiring Justice immediately replied, "My point is that if there is such an absolute Constitutional right, then that right exists in Chicago, North Dakota or Cincinnati or Detroit, as well as in Charlotte." Transcript of Oral Argument, Swann v. Charlotte-Mecklenberg, 402 U.S. 1 (1971), The Complete Oral ARUgments of -THE Supreme Court of the United STATES 1970 TERM 53 (emphasis added).

An insightful look into the Court's concerns appears in R. WoOdward \& S. ARMSTrong, The BRETHREN 101-02 (1979). A passage describes Justice Potter Stewart pondering the affirmance of District Judge McMillan's sweeping decision in Swann:

From Stewart's point of view, McMillan had put the Court on the spot. Two decades before, it would have been easier for the Court to back McMillan up. Then, Northern Democrats and Northern Republicans had given bipartisan support to the Court's desegregation orders. Although President Eisenhower had never enforced the orders with any enthusiasm, at least he had not campaigned against them as Nixon had done.

Id. at 101-02.

49. Swann, 402 U.S. at 22.

50. In the Topeka case, Brown v. Board of Educ., 98 F. Supp. 797 (D. Kan. 1951), plaintiff sought to enjoin enforcement of a Kansas statute that permitted cities with populations of over 15,000 to maintain segregated schools. In the other three cases joined, Briggs v. Elliott, $98 \mathrm{~F}$. Supp. 529 (E.D.S.C. 1951), 103 F. Supp. 920 (E.D.S.C. 1952); David v. County School Bd., 103 F. Supp. 337 (E.D. Va. 1952); and Belton v. Gebhart, 33 Del. Ch. 144, 87 A.2d 862 (1952), plaintiffs all sought to enjoin enforcement of state statutes and state constitutions that required the maintenance of segregated schools. See Brown I, 347 U.S. 483, 486 \& n.1 (1954).

51. 402 U.S. at 23. 
At the trial in Milliken v. Bradley, ${ }^{52}$ Judge Roth was forced to confront the limitations of focusing only on particular school boards when defining both the violation and the remedy. Roth realized that where a network of state policies had created a condition of inner-city racial containment, ${ }^{53}$ any remedy within the contained area would perpetuate rather than eliminate the discriminatory violation. Holding the state of Michigan ultimately responsible, Roth contemplated a busing remedy reaching into fifty-four white school districts surrounding the Detroit inner-city area. ${ }^{84}$

Roth's decree may have provoked the worst-remedy fears contemplated by the Supreme Court in Swann. ${ }^{.5}$ Where the violation was defined so broadly, the required matching remedy would affect thousands of whites who saw themselves as innocent, ${ }^{86}$ while inviting district courts to intervene broadly in local and state government without popular support.

The Supreme Court reacted in Milliken by limiting the violation, defining it as "Detroit-only," "'7 and parading the "horribles" involved in Judge Roth's remedial decree. ${ }^{.8}$ This discussion, however, exposed the Court's preoccupation with remedial crises. $^{59}$ The Sixth Gircuit had vacated

52. Bradley v. Milliken, 338 F. Supp. 582 (E.D. Mich. 1971), affd, 484 F.2d 215, 251-52 (6th Cir. 1973), rev'd, 418 U.S. 717 (1974).

53. See 338 F. Supp. at 587:

Governmental actions and inaction at all levels, federal, state and local, have combined, with those of private organizations, such as loaning institutions and real estate associations and brokerage firms, to establish and to maintain the pattern of residential segregation throughout the Detroit Metropolitan area . . . . For many years FHA and VA openly advised and advocated the maintenance of "harmonious" neighborhoods, i.e., racially and economically harmonious.

For an excellent account of the trial in Milliken, see P. Dimond, Beyond Busing (1985).

54. Bradley v. Milliken, 345 F. Supp. 914 (E.D. Mich. 1972). Judge Roth never actually ordered any busing decree; rather, he appointed a panel to prepare plans for an effective metropolitan desegregation remedy. Id. at 917 . See infra note 63.

55. See supra note 48.

56. The Supreme Court remains concerned about innocent third parties in anti-discrimination remedies. See Firefighters Local Union No. 1784 v. Stotts, 104 S. Ct. 2576, 2593 (1984) (O'Connor, $\mathrm{J}$., concurring) (district courts must "carefully balanc[e] the competing interests of discriminatees [and] innocent employees"). But see Schnapper, Perpetuation of Past Discrimination, 96 HARv. L. REV. 828, 846-47 (1983) ("Any claim of innocent third parties to be free from harmful consequences rooted in past discrimination is not superior to the constitutional rights of equally innocent black victims.").

57. Milliken, 418 U.S. at 746 ("The Constitutional right of the Negro respondents residing in Detroit is to attend a unitary district in that district.") (emphasis added).

58. See 418 U.S. at 743:

The metropolitan remedy would require, in effect, consolidation of 54 independent school districts historically administered as separate units into a vast new super school district .... Entirely apart from the logistical and other serious problems attending large-scale transportation of students, the consolidation would give rise to an array of other problems in financing and operating this new school system.

The Court then asked eight consecutive questions pertaining to remedial practicality. Id.

59. The Court was clearly worried about the Sixth Circuit's approval of the state responsibility ruling by the district court, see 418 U.S. at $734 \mathrm{n} .16$, and its conclusion that some interdistrict remedy would be necessary to prevent the Detroit schools from being all-black. Id. at 735; see Milliken v. Bradley, 484 F.2d at 238-41 (state-school board agency relationship); id. at 245 (interdistrict remedy 
Roth's remedial decree, ${ }^{60}$ and even Richard Nixon's Solicitor General, Robert Bork, had asked only that the case be remanded so as to join the affected suburban school districts and take evidence "concerning any constitutional violations involving the suburban districts and any interdistrict racially segregated impact of the Detroit violations."

The Supreme Court thus had a built-in opportunity to deliver a bifurcated opinion; with no remedial decree before it, the Court could have spoken purely in terms of the right involved. ${ }^{62}$ Instead, the Court carefully defined an intra-district, local school-board-oriented violation ${ }^{63}$ that allowed for matching intra-district remedies at the expense of exploring the deeper causes and potential cures for racial containment in the inner cities. ${ }^{64}$ The focus on local school boards that began as a remedial strategy in

necessary). Unwilling to permit a right-remedy gap or to allow the district court to become a "de facto legislative authority" or "school superintendent," 418 U.S. at 743-44, the Supreme Court chose to narrow the right to fit only an intra-district remedy. See supra note 57.

60. The Sixth Circuit had vacated the remedy and remanded to the district court with instructions that it join the affected district under FED. R. Crv. P. 19. See 484 F.2d 215, 251-52 (6th Cir. 1973).

61. See Memorandum for the United States as Amicus Curiae at 26-27, Milliken v. Bradley, 418 U.S. 717 (1974). To be sure, Solicitor General Bork argued for violation standards almost identical to those that the Court adopted. See id. at 10-22. Nonetheless, the remand suggested by Bork would have at least permitted further discussion of the connection of housing discrimination and school segregation in inner cities. By simply deciding that the violation was "Detroit-only," the Court was in effect saying that it was unwilling to look at the interdistrict effects of state-influenced housing discrimination.

In Milliken, the Supreme Court refused to consider housing violations because the Sixth Circuit had not relied on them. 418 U.S. at 728 n.8. This was a highly questionable procedural judgment. While plaintiffs had not pressed their "racial containment" theory before the Sixth Circuit as the sole grounds for affirming Judge Roth's ruling, they relied heavily on this theory (including its area-wide housing discrimination component) as an alternative ground for affirmance before the Supreme Court. See Brief for Respondents at 40-53, Milliken v. Bradley, 418 U.S. 717 (1974); Transcript of Oral Argument, reprinted in 80 LANDMARK BRIEFs AND ORAL ARguments 1222-26 (1980). Under traditional Supreme Court practice, plaintiffs are entitled to have such an issue either heard or remanded (as Bork had suggested) for further consideration. See R. STERn \& E. Gressman, Supreme Court Practice 53-54 (5th ed. 1978).

62. There is a wide agreement among scholars of different ideologies that the Supreme Court limited the conception of the violation in Milliken as a result of remedial pressures. See J. WILKINsoN, supra note 27, at 223-29; Fiss, supra note 3, at 47 (Burger Court using tailoring principle to limit right conception); Freeman, Legitimating Racial Discrimiation Through Antidiscrimination Law: A Critical Review of Supreme Court Doctrine, 62 MnN. L. REv. 1049 1107-11 (1978) (Court has used a "perpetrator" perspective to limit violations dealing with the victim's condition); Nagel, Separation of Powers and the Scope of Federal Equitable Remedies, 30 STAN. L. REv. 666, 715 (1978).

63. The Court was not deterred by the fact "that all of these vital operational problems are yet to be resolved by the District Court, and that this is the purpose of the Court of Appeals' proposed remand." 418 U.S. at 743.

64. In Milliken, Justice Stewart did acknowledge in a concurring opinion that inter-district busing might still be appropriate where the "state officials had contributed to the separation of the races by drawing or redrawing school district lines, . . . by transfer of school units between districts, . . . or by purposeful, racially discriminatory use of state housing or zoning laws." 418 U.S. at 755 (Stewart, J., concurring). Since Milliken, plaintiffs have occasionally been able to meet the burden required for inter-district remedies. See Evans v. Buchanan, 393 F. Supp. 428 (D. Del.) (three-judge court) (interdistrict remedy for Wilmington, Del.), affd, 423 U.S. 963 (1975) (per curiam); United States v. Board of School Comm'rs, 456 F. Supp. 183, 188-90 (S.D. Ind. 1978), aff'd in part and vacated in part, 637 F.2d 1101, 1108-10 (7th Cir.), cert. denied, 449 U.S. 838 (1980); see also Liddell v. 
Brown II had now become a means to limit state liability for equal protection violations.

The Court has relied on this narrow focus even when ruling in favor of minority plaintiffs. In both Keyes v. School District No. $1^{68}$ and Columbus $v$. Penick ${ }^{66}$ the Court justified strong remedial decrees, not by exploring the networks of state action that can cause or contribute to racial containment, but by overplaying the role of individual, or institution-specific fault in causing segregation. ${ }^{67}$

\section{Right-Declaration and Shaping Perspectives}

\section{A. Removing Focus from the State: The Perception of Hopelessness}

The trial courts in Swann, Milliken, Columbus v. Penick, ${ }^{68}$ and Evans v. Buchanan ${ }^{69}$ realized that, where the constitutional harm resulted from racial confinement in inner cities, no amount of reshuffling within the racially identifiable center city could in fact break down the state-fostered barriers that excluded black students from the societal mainstream. Effective responses to such segregative conditions, therefore, might require cre-

Missouri, 731 F.2d 1294 (8th Cir. 1984) (en banc) (implicitly recognizing state responsibility theory by approving voluntary interdistrict remedy largely funded by the state). For a discussion of the use of housing discrimination in interdistrict remedies, see Note, Housing Discrimination as a Basis for Interdistrict School Desegregation Remedies, 93 YALE L.J. 340 (1983).

65. 413 U.S. 189, 207-09 (1973).

66. 443 U.S. $449,461-68$ (1979).

67. In Keyes, Justice Brennan ordered district-wide relief by extending to anti-discrimination law the evidentiary presumption that proof of an individual's guilty intent in one sphere is prima facie grounds for presuming the same intent in highly related decisions. 413 U.S. at 207-09. This analysis so disturbed Justice Douglas that he wrote separately, criticizing Justice Brennan's quasi-criminal analysis and arguing that state policies that knowingly cause racial ghettoization are the components of an equal protection violation. Id. at 216-17 (Douglas, J., concurring) ("When a State forces, aids, or abets, or helps create a racial 'neighborhood,' it is a travesty of justice to treat that neighborhood as sacrosanct."). This has been the only time a member of the liberal wing of the Court has, in postBrown cases, written separately to criticize a favorable desegregation ruling.

The opinion in Columbus does not diverge from the school board focus either. Justice White ignored the variety of housing, investment, and real estate discrimination found by Judge Duncan at the trial, 429 F. Supp. 229, 258-59 (S.D. Ohio 1977), and instead wrote that the "systemwide segregation in the Columbus schools . . . was the result of recent and remote intentionally segregative actions of the Columbus [School] Board." 443 U.S. at 463-64.

68. 443 U.S. 449 (1979). At the trial level, Judge Duncan found that "housing segregation has been caused in part by federal agencies which deal with financing of housing, local housing authorities, financing institutions, developers, . . zoning and annexation . . ."429 F. Supp. at 259. Judge Duncan further found that the "interaction of housing and schools operates to promote segregation in each." Id.

69. Judge Caleb M. Wright found that specific policies of intentional discrimination were encouraged in the Federal Housing Administration mortgage underwriting manual. Evans v. Buchanan, 393 F. Supp. 428, 434 (D. Del. 1975). He also found that language in the Code of Ethics-published by the State-declared that "[a] realtor should never be instrumental in introducing into a neighborhood . . . members of any race. . . whose presence will clearly be detrimental to property values in that neighborhood." This language was not eliminated until 1970. Id. at 434-35. 
ative remedial responses from the state that would involve governmental institutions outside of the racially contained area.

By fragmenting state authority into local school districts for purposes of both the remedial reach of courts and defining the scope of equal protection clause violations, Milliken cramped the potential for both effective judicial and political responses to racial isolation. While restricting the use of inter-district busing partially stripped federal courts of a familiar remedial tool for alleviating racially identifiable school districts, compartmentalizing state authority in defining the right did something more: It meant that no governmental body with the capability to confront racial containment was under constitutional compulsion to come forth with any significant remedy at all.

Furthermore, after Pasadena City Board of Education v. Spangler, ${ }^{70}$ district courts no longer had jurisdiction even to confront alternative remedies where white flight caused resegregation. Thus, evasion of a desegregation decree became not only a remedial obstacle, but a basis for dispelling a constitutional violation. Through Milliken and Pasadena, the Supreme Court thus promoted the societal perception that those aspects of racial ghettoization that fell outside the narrowly defined violations were constitutionally legitimate ${ }^{71}$ and remedially hopeless.

Attributing responsibility to the state as a whole ${ }^{72}$ would alter the

70. 427 U.S. 424 (1976) (where white flight from school district or resegregation occurs, after decree has been implemented, district court does not have jurisdiction to modify decree to maintain integration). But see id. at 442-43 (Marshall, J., dissenting) (claiming that unitary system has never been reached, so initial decree was never fully implemented).

71. This critique of Milliken-that it served to legitimate racial ghettoization-is shared by J. Harvie Wilkinson, a recent Reagan appointee to the Fourth Circuit, and the author of the best conservative account of the post-Brown segregation decisions.

By ignoring housing, the Supreme Court began to lift from white America responsibility for the ghetto. Milliken v. Bradley was an act of absolution. Segregated Detroit schools were not the suburbs' creation and thus not their burden . . . "[w]hite society is deeply implicated in the ghetto. White institutions created it, white institutions maintain it, and white society condones it." Because the Court had been the last hope for blacks, its decision rang like a final sentence.

J. WiLkinson, supra note 27, at 224-25 (citation omitted). For the best account from a critical legal perspective, see Freeman, supra note 62, at 1102-19 (Milliken was integral in the "Era of Rationalization" of racial discrimination).

72. State responsibility implies not just that the state will be responsible for ensuring an intradistrict remedy, but that the state may not draw lines within itself to excuse itself from responsibility for remedying state-induced conditions of racial containment. This conception does not offend the rule that remedies must not exceed the scope of the violation. See Swann v. Charlotte-Mecklenberg, 402 U.S. 1, 16 (1970). Rather it recognizes that the state must be seen as part of the violation when it allows government-fostered racial discrimination to go unremedied within its jurisdiction. This conception secks only to harmonize current equal protection jurisprudence with the text of the Fourteenth Amendment. "[N]or shall any State . . . deny to any person within its jurisdiction the equal protection of the laws.", As Justice White wrote in dissent, the result of Milliken is that:

the State of Michigan, the entity at which the Fourteenth Amendment is directed, has successfully insulated itself from its duty to provide effective desegregation remedies . . . . The Court draws the remedial line at the Detroit school district boundary, even though the Fourteenth Amendment is addressed to the State and even though the State denies equal protection of the 
frameworks in Milliken and Pasadena that promote perceptions of hopelessness and false legitimization. When courts view a fragment of the state (e.g., a local school district) as the party remedially responsible for segregation, flight from or racial isolation of that district denies possibilities of meaningful remedies while allowing for judicial denial of the continuation of constitutional harm..$^{73}$ When courts view the state as a whole as responsible, white flight and racial containment, however troublesome as remedial obstacles, ${ }^{74}$ would not obscure the judicial recognition and societal perception of constitutional tension.

From this vantage point, one can unscramble the fundamental paradox of Justice Powell's contention that where only majoritarian processes can fully remedy social ills such as racial containment, federal courts should limit their findings of constitutional violations. ${ }^{75}$ Courts are inextricably and unavoidably actors in the political environment. Through their right declarations and findings, courts either inspire or inhibit the political processes that Justice Powell thinks suitable to create complex remedies. ${ }^{78}$

laws when its public agencies, acting in its behalf, invidiously discriminate. The State's default is the "condition that offends the Constitution."

418 U.S. at 763, 771-72 (White, J., dissenting) (emphasis in original); see Cooper v. Aaron, 358 U.S. 1, 16-17 (1958) (" "Whoever, by virtue of public position under a State government, . . . denies or takes away the equal protection of the laws, violates the constitutional inhibition; and as he acts in the name and for the State, and is clothed with the State's power, his act is that of the State.'") (quoting Ex parte Virginia, 100 U.S. 339, 347 (1880)); see also Dimond, supra note 45, at 6 ("[T]he anticaste principle does not permit judicial compartmentalization of overall governmental responsibility for caste discrimination."); Schnapper, supra note 56, at 842 ("The division of responsibility among several officials should not affect the underlying constitutional obligation of the state that employs, and acts through, all of them."); Note, supra note 64, at 346 ("[S]tate officials cannot escape the force of the equal protection clause simply by splintering or rearranging authority.").

73. Ironically, states have displayed their multi-faceted power to affect racial balance most vividly in attempting to avoid segregation. See, e.g., Griffin v. County School Bd., 377 U.S. 218, 221-25 (1964) (Virginia and Prince Edward County manipulated state constitution, tuition grants, tax laws, and property tax credits to keep public schools in Prince Edward County closed for five years and avoid desegregation). With the state generally exempted from ultimate responsibility for desegregation, "only a very limited effort appears to have been made to conduct research on the efficacy of state action [in school desegregation]." Center for Educ. and Hum. Dev. Pol., State Strategies FOR Reducing Isolation 2 (1981). Yet the National Project and Task Force on Desegregation Strategies finds that "as the 1980s begin, the single most promising strategy for progress in school desegregation may well be that of state initiative." STATE Leadership TOWARD DeSEgREgating Education: A Positive Future 5 (1980). See generally C. Willie, School Desegregation Plans THAT WORK 29-39 (1984) (importance of state responsibility in school desegregation).

74. See Gewirtz, supra note 6, at 532-35. Professor Gewirtz presents the difficulty of implementing effective desegregation decrees, even for "rights-maximizing" judges, considering the realities of white flight. Id. Gewirtz' article assumes that courts only have jurisdiction over local school authorities. Where, however, the state as a whole is responsible, white flight would be less of an obstacle to right-maximization, because the means for combating flight and containment would be greatly expanded.

75. Estes v. Metropolitan Branches of Dallas NAACP, 444 U.S. 437, 451 n.18 (1979) (Powell, J., dissenting from dismissal of certiorari) ("Because the causes of segregation in residential housing are usually beyond judicial correction, wider solutions that will be acceptable to concerned parents must be sought by legislators and executive officials.").

76. Justice Powell's opinions are the most susceptible to the claim that remedial concerns are affecting both the scope and the findings of constitutional violations. Powell has often sought to deny 
While the Supreme Court confronted worst-remedy cases in both Brown and Milliken, by bifurcating its opinion in Brown the Court at least created a constitutional vision gap that encouraged a constructive political response. In Milliken, by contrast, the Court encouraged social complacency by formulating the violation so narrowly as to close any remedial gap between constitutional values and the conditions of racial ghettoization. ${ }^{77}$ The Court thereby squandered the opportunity to make the major-

equal protection violations while basing much of his argument on remedial considerations. His discussion of remedies in Estes, see supra note 75, echoes his arguments in Columbus v. Penick, 443 U.S. 449, 479 (1978) (Powell, J., dissenting), where, in opposing the majority's finding of a system-wide violation, he argued that "restructuring and overseeing the operation of major public school systems-as ordered in these cases-fairly can be viewed as social engineering that hardly is appropriate for the federal judiciary . . . " Id. at 487. See also San Antonio Indep. School Dist. v. Rodriguez, 411 U.S. 1, 56 (1972) (Powell, J.) (articulating concerns about "practical ramifications" of holding Texas" public financing system unconstitutional; asserting that "[T]he constitutional judgment ... approved by our dissenting Brothers today would occasion in Texas and elsewhere an unprecedented upheaval in public education .... there is nothing simple or certain about predicating the consequences of massive change in the financing and control of public education.") But see id. at 58 (Powell's interesting disclaimer: "These practical considerations, of course, play no role in the adjudication of the constitutional issues presented here. But they serve to highlight the wisdom of the traditional limitations on this Court's function.").

Justice Powell's opinions on the intent requirement also support the contention that remedial concerns have influenced his rulings on violations and even standing. In Keyes v. School Dist. No. 1, 413 U.S. 189 (1973), Powell essentially bifurcated his attack on busing remedies from his discussion of the violation and issued an opinion highly critical of the intent standard and the de facto/de jure distinction. Id. at 224 (Powell, J., concurring in part and dissenting in part) ("I would not, however, perpetuate the de jure/de facto distinction nor would I leave to petitioners the initial tortuous effort of identifying 'segregative acts' and deducing 'segregative intent.'"). In Warth v. Seldin, 422 U.S. 490 (1975) Powell continued to de-emphasize racial considerations in the decisionmaking process. Powell, in fact, denied standing by requiring a nearly impossible burden of proof as to the likelihood of harmful impact. After the imposition of the process-oriented intent standard for an equal protection violation, Washington v. Davis, 426 U.S. 229 (1976), Powell perhaps realized that the intent standard, because of its "tortuous" evidentiary burden, is a more effective means to limiting violations, such as residential zoning and school desegregation, that lead to the wide-ranging judicial remedies he objects to. In Village of Arlington Heights v. Metropolitan Hous. Dev. Corp., 429 U.S. 252 (1977), Powell completely flip-flopped, de-emphasizing the importance of discriminatory impact in determining standing and constitutional violations, and issued instead, one of the narrowest discriminatory purpose rulings.

The suggestion that Justice Powell might declare broader rights were he to bifurcate his rightremedy rulings finds support in Fullilove v. Klutznick, 448 U.S. 448 (1980). In that case, where a majoritarian institution had devised the remedy, Powell was more willing to accept claims that group inequality is causally related to past discrimination. "Although the discriminatory activities were not identified with the exactitude expected in judicial or administrative adjudication, it must be remembered that 'Congress may paint with a much broader brush than may this Court . . . ." Id. at 503, 506 (Powell, J., concurring) (citation omitted).

77. Had the Supreme Court sought to confront the full depth and intricacies of racial containment in Milliken v. Bradley or other segregation cases in the 1970's, a remedial gap likely would have resulted. However great the immediate remedial neglect, political reality does not stand still. The 1982 Voting Rights Act Amendments, Pub. L. No. 97-205, 96 Stat. 131 (codified at 42 U.S.C. §§ 1971,1973 to $1973 \mathrm{bb}-1$ (1982)), the increase in the number of minority mayors in large cities, and increased voter turnout among minorities, see T. Cavanagh \& D. StockTon, Black Elected Officials AND Their ConstruUencies (1983), together may have enhanced the potential for majoritarian remedies had the problems of northern caste at least remained on the political agenda during the decade since Milliken I. Surely Jesse Jackson, as Dr. King before him, could have invoked a decade-long constitutional gap to stir majoritarian conscience. But Milliken did not proclaim rights; it did not stir ideals or create political tension. Instead, it fulfilled the prophecy of Gunnar Myrdal, 
ity confront the discrepency between its constitutional values and the conditions of historically outcast groups. ${ }^{78}$ The problem thus is not only that, as Justice Powell recognizes, there are limits to law in bringing social justice, but also that law may be quelling the social processes that generate social justice.

\section{B. Narrowing Dialogue; Limiting Choices}

By consistently severing off the conditions of schools and the action of local school boards from the broader problem of racial containment, the Supreme Court encouraged scholarly and public debate ${ }^{79}$ over a false issue: Could purely school-oriented desegregation decrees bring quantifiable improvements to young minorities residing in the nation's slums and ghettos? ${ }^{80}$ Within this public dialogue, the merits of any substantial governmental effort to attack past state-fostered discrimination often became reduced to analyzing whether or not racial busing improved scores on standardized educational tests. Where school desegregation remedies have not quickly improved test scores many have denigrated school desegregation remedies and overlooked the limited scope of the remedial approach compared to the breadth and complexity of the problem. Judicial recognition of racial containment and the obligation of the State to address it might have encouraged remedies responsive to racial isolation other than busing and other pupil-assignment remedies. ${ }^{81}$

see G. MYRDAL, supra note 43, at 617-52, by removing the problems of racial containment from national consciousness and constitutional analysis just as the very process of racial isolation had physically removed the problems of discrimination from the eyesight and everyday lives of much of white America.

78. Sometimes the prestige of the Supreme Court causes right-declaration alone to inspire immediate majoritarian remedies. Over three hundred school districts moved to desegregate voluntarily between Brown I and Brown II. See H. Rep. No. 914, 88th Cong., 2d Sess. reprinted in 1964 U.S. ConG. Code \& AD. News 2391, 2504. Recently, in Roberts v. United States Jaycees, 104 S. Ct. 3244 (1984) the Supreme Court ruled that the Minnesota Supreme Court was justified in finding that the local Jaycee chapter did fall within the meaning of a public accommodation and thus could not deny women full membership under the Minnesota Human Rights Act. While the ruling had force only in Minnesota, the National Jaycees immediately changed their national bylaws to allow women. See Jaycees Vote to Admit Women to Membership, N.Y. Times, Aug. 17, 1984, at A8, col. 1.

79. See Craine \& Mahard, Desegregation and Black Achievement: A Review of the Research, 42 LAw \& Contemp. ProBs. 17, 17 (1978) ("[A]chievement tests have received an undeserved emphasis in the desegregation literature . . . [and] the emphasis is embarrassing.").

80. Evidence generally indicates that school desegregation does improve minority test scores. See Daniels, In Defense of Busing, N.Y. Times, Apr. 17, 1983, § 6 at 34, col. 2; see also Craine \& Mahard, supra note 79, at 48 (most tests show gains for minorities, but such studies inherently problematic). But see Werner, Busing and Quotas Assailed by Meese, N.Y. Times, Mar. 16, 1985, at 40 , col. 6 (Attorney General Meese stating "it's generally recognized in educational as well as legal circles that school busing has had a marginal effect as far as improvement is concerned, and actually in some cases has added to the deterioration of the situation"). Whatever the merits of such studies, the public and scholarly focus on the results has often detracted from the true constitutional issue: the governmental obligation to remedy the effects of discriminatory state action that have left barriers to first-class citizenship.

81. Professor Dimond argues that while a broader conception of constitutional violation would 


\section{Right-Declaration and Remedial Expectations: Statutory Examples}

While bifurcation raises the danger of de-emphasizing the enforcement of minority rights, ${ }^{82}$ the expectations created by right-declaration may enhance political awareness, provoke the interest of the media and social researchers, and eventually lead to full relief..$^{83}$ Civil rights progress often proceeds in stages. Title VII had serious enforcement shortcomings when passed in 1964. Yet the Act enhanced societal expectations of equal employment opportunities which inspired tougher remedial mechanisms under state statutes and the 1972 Amendments to Title VII. ${ }^{84}$

involve more levels of the state, it would allow state governments more opportunities to alleviate caste barriers without busing if they so desired. See Dimond, supra note 45 , at $42-48$. A governmental responsibility approach would require courts to shift from a quasi-criminal perspective to a more appropriate modern tort law approach in confronting entrenched discrimination. Cf. G. CALABRESI, THE COSTS OF ACCIDENTS (1970) (emphasizing cost-spreading over individualistic fault).

82. This danger is real and should be seen as the major problem with the theory of judicial review advocated in this Note. See infra notes 93-97 and accompanying text. Full remedies for decades of entrenched discrimination, however, require a long-term remedial commitment. South Burlington County NAACP v. Township of Mt. Laurel, 92 N.J. 158, 456 A.2d 390 (1983) (Mt. Laurel II), provides a significant case study. In 1975, the New Jersey Supreme Court approved a 1973 finding that Mount Laurel should remedy its long-standing discriminatory zoning policy. Mount Laurel I, 67 N.J. 151, 336 A.2d 713 (1975). This was a pure case of a bifurcated right-declaration with an almost complete remedial gap. "[T]en years after . . Mount Laurel remains afflicted with a blatantly exclusionary ordinance . . . there is widespread non-compliance." 92 N.J. 198-99, 456 A.2d 410. The court, however, declared itself "more firmly committed to the original Mount Laurel doctrine than ever, and . . . determined, within appropriate judicial bounds, to make it work." Id. Within a year of Mt. Laurel II, public debate had turned to how and who should control and bear the costs for the required low income housing construction. See Sullivan, Builders Assail Kean on Mt. Laurel Stand, N.Y. Times Jan. 20,1984, at XI: 1, col. 1. While the case itself is certainly controversial, the construction of substantial housing is assumed, and the implementation problems are receiving great attention from the state legislators as well as social science researchers at Rutgers and Princeton. See Oser, Jersey Town Faces Mt. Laurel Mandate, N.Y. Times, Jan. 20, 1984, at VIII: 7, col. 1.

83. The breadth of the right declared-even if not fully remedied by the judiciary-may expand what state and federal courts see as permissible majoritarian remedies authorized by $\S 5$ of the Fourteenth Amendment, by the spending powers clause, and by state legislatures. Conversely, federal courts should permit Congress (under $\S 5$ of the Fourteenth Amendment) and state courts to expand protection of constitutional rights to their full measure, where previous constitutional rulings had been limited because of concern for judicial competence and not because the federal courts had expressed the outer limits of the constitutional norm. See Sager, Fair Measure: The Legal Status of Underenforced Constitutional Norms, 91 HARv. L. REv. 1212, 1213 (1978). This Note shares a fundamental conception expressed by Professor Sager: Where institutional concerns cause federal courts to narrow constitutional rights, the breadth of constitutional rights should not be seen as coterminous with federal judicial enforcement. Unlike this Note, however, Sager presents the federal judiciary as reactive. After Congress or state courts act to broaden constitutional rights, Sager suggests that the Supreme Court can justify its deference by recognizing, post-facto, that a gap had previously existed between the breadth of the constitutional norm and federal judicial enforcement. Id. at 1239-40, 1247-50. If a gap exists, however, why should an independent judiciary not take the initiative and define the full right? Sager may be implicitly contending that despite the Supreme Court's role as final arbiter, "Congress and state courts [may help] to shape elusive constitutional norms at their margins." Id. at 1264. Nonetheless, the failure to act first may serve to legitimize a condition at odds with constitutional norms. See Wright, supra note 8.

84. While Title VII of the Civil Rights Act of 1964 is the landmark legislation that outlawed employment discrimination, see Pub. L. No. 88-352, 78 Stat. 241 (1964), a gap between the right and its enforcement existed after the act's passage. The Equal Employment Opportunity Act of 1972 sought to address this problem by giving the Equal Employment Opportunity Commission enforce- 
In Los Angeles Department of Water and Power $v$. Manhart ${ }^{85}$ the Supreme Court declared differential pension contributions by sex violative of Title VII, while denying retroactive relief. Make-whole relief, according to the Court, might involve fifty million workers and $\$ 400$ billion of retirement reserves. ${ }^{88}$ Whether or not such worst-remedy fears were valid, the Court, by bifurcating its decision, declared a powerful prospective right that altered public perspectives and fueled the processes that led to national legislation in $1984 .^{87}$

\section{Bifurcation and Value Formation}

Disputes over ideals often mask concern over the burdens or benefits the realization of those ideals would have on the self-interest of existing parties. ${ }^{88}$ When the Supreme Court restrictively defines rights in times of remedial resistance or impracticability, it allows one majority's resistance-or cost-benefit decision-to limit the societal visions and constitutional ideals passed on to future generations. ${ }^{88}$ Conversely, by stressing

ment powers and by expressly giving judges more flexible remedial powers. See Pub. L. No. 92-261, 86 Stat. 103 (codified at 42 U.S.C. $\$ 2000 \mathrm{e}-1$ (1976)). The right declared in 1964 created pressure for these broader remedial measures which would have had little chance of passage in 1964. The Conference Report in 1972 read:

Despite the commitment of Congress to the goal of equal employment opportunity for all citizens, the machinery created by the Civil Rights Act of 1964 is not adequate.

Despite the progress which has been made since passage of the Civil Rights Act of 1964, discrimination against minorities and women continues. The persistence of discrimination, and its detrimental effects require a reaffirmation of our national policy of equal opportunity in employment. It is essential that seven years after the passage of the Civil Rights Act of 1964, effective enforcement procedures be provided the Equal Employment Opportunity Commission to strengthen its effort to reduce discrimination in employment.

H.R. ReP. No. 238, 92d Cong., 1st Sess. (1971), reprinted in 1972 U.S. Code Cong. \& AD. News 2139.

85. 435 U.S. 702 (1978). Manhart was the first major litigation effort to challenge differential pension contributions based on the longer lifespan of women. See Manhart v. Los Angeles Dep't of Water and Power, 652 F.2d 904, 908 n.3 (9th Cir. 1981) (liberal award of attorneys fees based partly on risk taken by lawyers because "case was the first to challenge pension contribution [sex] differences"). Justice Stevens was clearly concerned that full retroactive relief might penalize pension managers and investors who had no reason to believe they were violating the spirit or law of Title VII. Rather than avoid a broad right-declaration in order to minimize his worst-remedy concerns, Stevens declared a right to sex-neutral pension contributions and relied on the grant of equitable discretion under Title VII to deny retroactive relief for those particular claims. See 435 U.S. at 723 ("Without qualifying the force of the Albermarle presumption in favor of retroactive relief, we conclude it was an error to grant such relief in this case.").

86. 435 U.S. at 721.

87. Retirement Equity Act of 1984, Pub. L. 98-397, 98 Stat. 1426.

88. See generally J. RAwLs, A Theory of Justice 136-42 (1971) (discussing the contemplation of justice from a "veil of ignorance").

89. There is much agreement that courts have a strong impact on societal ideals. See, e.g., A. Cox, The WARREN Court 27 (1968) ("The Court is often the voice of the national conscience. The justices shape, as well as express, our natural ideals. Brown $v$. Board of Education restated the spirit of America and lighted a beacon of hope for Negroes at a time when other governmental voices were silent.").

The assertion that non-coercive judicial words can affect values and political and legal developments 
equal protection ideals even when there is an unwillingness to bear remedial costs, the Court may affect the conscience and consciousness of future generations and influence them to address any continuing legacy of slavery and caste segregation..$^{80}$

Judicial-especially Supreme Court-proclamations do not affect only the majority's values and world views. The dispensation of such symbols may strongly affect the degree of recognition and community a disadvantaged minority group feels with the society at large. ${ }^{9 x}$ The monopolization of such symbols by an effective majority may enhance, if not create, the self-perception of powerlessness. ${ }^{92}$ In his classic novel, Invisible Man, Ralph Ellison illuminated for American society that the pain felt by minorities came not only from economic disadvantage and discrimination, but also from the frustration of having their identity, problems, and concerns go unrecognized, unacknowledged-invisible - by the society that surrounds them. ${ }^{93}$

Brown $I$ at least broke the barrier of constitutional invisibility: The equal protection clause was no longer blind to the social reality of black Americans. The recognition of one's rights, of course, may lead to rising expectations, and rising frustration where a remedial gap exists. Apologists for the status quo may thus be wary of both creating and legitimizing expectations they are unwilling or unable to fulfill. Conflict and tension

is hardly novel. Dissents and concurrences represent non-coercive judicial words that have at times had significant societal and legal impacts.

90. Law school initially grinds the legal and constitutional lenses through which most lawyers, and many politicians and policymakers, see social reality. The law student enters her first year with pre-existing opinions about what is good or bad, but quickly begins to learn which things are legally cognizable. Students studying the major segregation cases discover the following memorizable lesson: Racially identifiable school districts are not constitutionally wrong unless the inhabitants can prove that the racially motivated acts of particular school officials caused their isolated status.

Imagine instead that law students learned that courts held racial containment in several inner cities to violate the Constitution, but that few states had proffered adequate remedies. Racial ghettoization, instead of being legitimated through law, would instead invoke the perception of a constitutional gap-a gap striking at the integrity of the student's profession. Right-declaration can determine whether racial ghettoization is seen as a constitutional non-issue or as a compelling remedial challenge to all those concerned either with the substantive goals of the equal protection clause or with the necessity that a society founded on the rule of law provide remedial justice.

91. Cf. P. Bachrach \& M. Baratz, Power AND Poverty 8 (1970) (" $[T] 0$ the extent that a person or group-consciously or unconsciously-creates or reinforces barriers to the public airing of policy conflicts, that person or group has power."); E. SCHATTSCHNEIDER, THE SEMI-SovEREIGN PEOPLE 71 (1960) ("Some issues are organized into politics, while other issues are organized out."); M. Edelman, The Symbols of Polmitics (1964).

92. See J. Gaventa, Power and Powerlessness 15 (1980) ("IT]he means through which power influences, shapes, or determines conceptions of necessities, possibilities, and strategies . . . may include the study of social myths, language and symbols, and how they are shaped or manipulated in power processes . . . . It may involve a focus upon the means by which social legitimations are developed .....").

93. See R. Ellison, Invisible Man 4 (1947). ("You ache with the need to convince yourself that you do exist in the real world, that you're a part of all the sound and anguish, and you strike out with your fists, you curse and you swear to make them recognize you. And alas, it's seldom successful."). 
will be inevitable. Yet refusing to recognize injustice because its admission may energize a victim to seek his justice is an inappropriate response for an independent judiciary. Remedying the effects of long-term discrimination will of course bring forth tension, but as Justice Blackmun wrote in Bakke, such "tension is original Fourteenth Amendment tension, constitutionally conceived and constitutionally imposed, and it is part of the Amendment's very nature until complete equality is achieved." ${ }^{94}$

\section{Bifurcation and Judicial Legitimacy}

The Bill of Rights and Article III of the Constitution reflect the Framer's desire to ensure that neither individuals nor unpopular minorities could be deprived of their rights simply by majority will. ${ }^{95}$ The need for an independent judiciary to protect constitutional rights from political whims and majoritarian hostility has proven to be especially critical for discrete and disadvantaged minorities. ${ }^{96}$ For while the protection of one individual's free speech protects all citizens' rights to utter unpopular views, such universal self-interest does not exist to check majorities from continually disadvantaging minorities and outgroups. ${ }^{97}$

The structural relief necessary to remedy entrenched discrimination, however, poses threats to the independent judicial protection of minority rights. Structural relief is often dependent on the acquiescence of majoritarian institutions that are both responsible for past violations and yet in control of the police powers necessry to enforce a judicial decree. A court's heightened vulnerability to the political branches in enforcing its

94. University of Cal. Regents v. Bakke, 438 U.S. 265, 405 (1978) (Blackmun, J., separate opinion).

95. See The Federalist No. 78, at 508 (E. Earle ed. 1937) ("This independence of the judges is equally requisite to guard the Constitution and the rights of individuals from the effects of those ill humors, which . . . have a tendency . . . to occasion . . . serious oppressions of the minor party in the community."). This judicial function was given heightened importance in the twentieth century. See United States v. Carolene Prods. Co., 304 U.S. 144, 152 n.4 (1938) (courts should apply a more "searching judicial inquiry" to protect "discrete and insular minorities."). See generally J. ELY, DEMOCRACY AND DisTrust (1980) (judicial review should cleanse political process of majoritarian abuses against minorities).

96. Leading commentators have always recognized that a vital role of our independent federal judiciary is to transcend times of political passion to protect important values. See, e.g., A. BickEL, supra note 2, at 26 ("Their insulation and their marvelous mystery of time gives courts the capacity to appeal to men's better natures, to call forth their aspiration, which may have been forgotten in the moment's hue and cry."); C. Black, The People and the Court 107 (1960) (federal courts are "the people's institutionalized means of self-control"); see also Wellington, The Nature of Judicial Review, 91 YALE L.J. 486, 493 (1982) ("Because they often deflect the momentary passions of the majority, countermajoritarian political forces may well provide protection for longer range concerns in politics.").

97. Both the United States Civil War and fascism in Europe increased American awareness of the dangers of unconstrained majoritarianism where the interests of identifiable minorities are involved. See Cover, The Origins of Judicial Activism in the Protection of Minorities, 91 YALE L.J. 1287, 1289 (1982) (In "age of Hitler," majoritarianism requited greater justification). 
remedial decrees, however, must not constrain consideration of the right. Because such remedial dilemmas arise in direct proportion to both the depth of past wrongs and past remedial inadequacy, such tensions are an inappropriate reason for an independent judiciary to narrow or deny constitutional rights.

Countering the case for bifurcation, however, is the claim that bifurcation would destroy judicial legitimacy by encouraging decrees that would be subject to noncompliance and ultimate nonenforcement. While issuing decrees poses some threat to judicial legitimacy, constrained rightdeclaration poses a greater threat. To alter judicial declarations of individual or minority rights because of majoritarian or political pressures is to abdicate fundamental judicial responsibility within the constitutional system. ${ }^{98} \mathrm{~A}$ refusal of the majority to close the gap between rights and remedy speaks primarily to the lawfulness and legitimacy of the society, not necessarily to the legitimacy of an independent judiciary. Writes Dean Jesse Choper, "Acceptance is not the Court's responsibility, but the obligation of the people; execution not its onus, but the duty of political branches." "9g

Bifurcation poses another potential danger. However formalistic the obligation to match full remedies to declared rights may be, that obligation pressures judges to seek the actualization of the results they declare to be just. Bifurcation could legitimize weak or insufficient remedies. Several responses to this challenge should be considered.

First, the Supreme Court has, when faced with undesirable remedial cases in the last fifteen years, retracted rights, which obviously results in an inadequate remedy. If remedial inadequacy is the constant under both frameworks, then bifurcation at least offers the benefits of rightdeclaration. ${ }^{100}$ Second, bifurcation does not necessarily lead to narrower or

98. See Stone, The Common Law in the United States, 50 HARv. L. Rev. 4, 25 (1936) (special role of courts is to provide "the sober second thought of the community"); A. BickEL, supra note 2, at 24 (courts are "the pronouncer[s] and guardian[s] of such values"). One of the few dialogues on the legitimacy of gaps, however, took place in The New Republic when Bickel criticized Judge Skelly Wright for making a judicially unenforceable right-declaration in a Washington, D.C. segregation case. Bickel, Skelley Wright's Sweeping Decision, The New RepuBlic, July 8, 1967, at 11-12. Michael Tigar came to Wright's defense in a response the next month:

Professor Bickel's error is in assuming that a judge cannot denounce the conduct of litigants unless he is able to provide a complete remedy. As Professor Bickel's own writings have wellrecognized, however, one great purpose of revoluntionary judicial utterance-like Brown v. Board of Education-is to set at large with official imprimatur ideas which have theretofore gone unspoken. This hortatory function of judging serves at times to legitimize struggle elsewhere in society to attain the ends put into practice the ideas first set out by judges. Certainly this has been one salutary effect of Brown.

Tigar, In Defense of Skelly Wright, The New Republic, Aug. 5, 1967, at 43.

99. J. Choper, Judicial Review and the National Political Process 168 (1980); see also Marbury v. Madison, 1 Cranch 137 (1803) ("It is emphatically the province and duty of the judicial department to say what the law is.").

100. In determining the effect that bifurcation will have on remedies delivered to minority plain- 
broader remedies. Bifurcation simply separates consideration of the right from that of the remedy, to protect agreement on the right from the inappropriate influence of remedial fears. Third, judges who unnecessarily deny effective remedies, ${ }^{101}$ as well as judges who order massive, wideranging remedies, will be subject to judicial review and developing standards for judicial discretion in different contexts. Judges will still be obligated to actualize justice to the best of their abilities. Judges that leave a right-remedy gap ${ }^{102}$ will be forced candidly to articulate the balancing considerations that led to their remedial order, so that courts, scholars, and the public can review them. ${ }^{103}$

Fourth, where intense political and economic strains are associated with

tiffs, one must look not to the difference between right and remedy, but rather to the difference between remedies delivered in a bifurcated decision and remedies given in a unified decision. See supra note 7 (discussion of bifurcation in Brown). If remedial costs are the core conflicts, and a judge is willing in a bifurcated analysis to deliver-on a scale from one to ten-a "ten" right and a "five" remedy, but in a unified approach only a "five" for both, then the gap resulting from bifurcation represents a broader right-declaration, not a cheaper remedy.

101. While this Note has focused on the judicial decisionmaking process, its thesis is also relevant to the legal strategies of lawyers. A lawyer bringing a comparable worth case, for example, may fear that her claimed violation is so broad that the relief would be unmanageable. Instead of narrowing her claim so as to make the necessary relief plausible to the court, the lawyer might stress to the court that, considering the novel and important nature of the case, the court should bifurcate its considerations and focus exclusively on the right at the first stage. While such a sharp bifurcation may give the court room to leave a right-remedy gap, a lawyer might still push for this where she feels the violation may be narrowed or denied due to remedial concerns, and where the right-declaration itself may have positive political and societal ramifications. See supra text accompanying notes 85-86 (discussion of Manhart).

Such strategies have not been unfamiliar in worst-remedy school cases. In San Antonio Indep. School Dist. v. Rodriquez, 411 U.S. 1 (1972), plaintiff's Motion to Affirm explicitly sought a bifurcated opinion:

In the present case, the Plaintiffs seek merely to enjoin a system that denied them equal protection of the laws. . . . The state is left to choose among a variety of systems . . . Since many legislatures are enacting public school education systems to meet State and lower Federal

Court decisions future determination will give the Court greater opportunity to view the effect of the relief sought.

Id. at 11 .

102. Another significant danger in requiring right-remedy matching is not simply that judges will narrow rights, but that judges unwilling to deliver controversial remedies will develop standing requirements, see Warth v. Seldin, 422 U.S. 490 (1975), or evidentiary requirements, see Arlington Heights v. Metropolitan Hous. Corp., 429 U.S. 252 (1978), that will lead to the refusal to declare any violation at all. See Note, Making the Violation Fit the Remedy: The Intent Standard and Equal Protection Law, 92 YALE L.J. 328 (1982) (controversial voting rights remedies encouraged intent standard for fundamental rights case); see also Note, Discriminatory Purpose and Mens Rea: The Tortured Argument of Invidious Intent, 93 YALE L.J. 111, 134 (1983) (lack of candid remedial balancing responsible for development of highly restrictive intent standard).

103. Candor over the substantive visions encompassed in right-declarations also enhances societal understanding of the values and value conflicts that characterize a constitutional provision. In fact, our current understanding of the equal protection clause is partly informed by our rejection of the values candidly condoned in Plessy v. Ferguson, 163 U.S. 537 (1896) (state-fostered racial separation intended to be neither stamp of second-class citizenship nor fit subject for law), and Bradwell v. Illinois, 83 U.S. (16 Wall.) 130, 141 (1873) (Bradley, J., concurring) (denial of license to practice law because "paramount destiny and mission of womanhood are to fulfill the noble and benign offices of wife and mother."). See Gewirtz, supra note 6, at 670 (making strong argument that candor protects broader rights in anti-discrimination law). 
complete remedies, tendencies may exist for judges to alleviate dissonance ${ }^{104}$ provoked by a right-remedy gap, by narrowing the right to match the remedy. Bifurcation could serve as an internal check on the judiciary to insure that such dissonance leads to confrontation-and not legitimation -of pervasive constitutional wrongs. ${ }^{105}$

Finally, remedial obstacles tend ultimately to find their origin in past discrimination. Even if a parent opposed busing or redrawing school district lines on non-racist grounds, that opposition to particular remedies is nevertheless linked to effective desegregation by past state policies that originally fostered the segregation and the need for remedies. The severity of even legitimate obstacles to effective desegregation will be proportionate to the effectiveness of past discrimination in physically and psychologically separating the races. To retract-even slightly-the right at stake because of such obstacles, serves to perpetuate the power of past discrimination in the guise of alleviating it. Where the wrong is deep enough, and if rightremedy matching is required, social reality will almost compel a discriminatory jurisprudence of anti-discrimination law. ${ }^{106}$ Bifurcation allows

104. See L. Festinger, $\Lambda$ Thkory of Cognrtive Dissonance 3 (1962) ("The existence of dissonance, being psychologically uncomfortable, will motivate the person to try to reduce the dissonance and achieve consonance."). Notably the first example in this book is "[a] person may think Negroes are just as good as whites but would not want any living in his neighborhood." Id. at 1. Festinger also cites Myrdal's An American Dilemma as a "good statement of some of the reasons why strong dissonance exists in this area." Id. at 7. In light of the Supreme Court's continued refusal to consider the housing discrimination found by the trial courts in recent segregation cases, it is worth noting that the second half of Festinger's basic hypothesis is that "the person will actively avoid situations and information which would likely increase dissonance."

105. Professor Gewirtz advocates a position with which this Note is in agreement: Rightdeclaration can ultimately serve the ideal value at stake. See Gewirtz, supra note 6, at 670-74. Gewirtz' article, however, admittedly assumes that the right will remain static regardless of the contemplated remedy. Id. at 593 n.17. Under this assumption, Gewirtz' willingness to have a judge shutule back and forth between right and remedy seems reasonable. Id. at 679 . This Note contends, however, that the very crux of the post-Swann cases has been the negative, backwards dynamism between the remedy and the right. Where a court is dependent on a hostile majority for the implementation of a corrective structural remedy, the tendencies to narrow rights will often be powerful. In rejecting Owen Fiss' discussion of bifurcation, id. at 677-80, Gewirtz gives far too little attention to the role that bifurcation may play as an institutional mechanism to check both against the compromising of judicial independence and against the potential for judicial dissonance to be soothed by contracting the right to fit the remedy.

Because Gewirtz seems to desire a powerful role for right-declaration in the face of remedial crisis, it is surprising that he never adequately discusses whether bifurcation may be the best judicial policy to achieve such objectives. Instead, he tells us only that judicial legitimacy problems "cannot be solved" by bifurcation. Id. at 679-80 (emphasis added). Yet neither Fiss, nor this Note, contend that bifurcation can solve all problems of judicial legitimacy in the way a new medical discovery cures a disease. In fact, the thrust of Fiss' discussion, see Fiss, supra note 3, at 51-58, is that the problem of remedial implementation and judicial independence is a core dilemma that defies ultimate solution but must be resolved as well as possible. Ultimately, bifurcation as advocated in this Note would best facilitate the role of law that Gewirtz advocates elsewhere in his article. See Gewirtz, supra note 6, at 587-95, 665-74.

106. This tendency for remedial obstacles for minority rights to be linked to past discrimination justifies a strict conceptual bifurcation to prevent inappropriate remedial factors from tugging at and restricting the right. But see Gewirtz, supra note 6 , at 676 ("[J]udges may take account of . . . even 
equal protection ideals to survive remedial obstacles, and in turn, to generate a climate that inspires society to confront and conquer them.

In analyzing the strains that segregation places upon the judiciary, it too often goes unrecognized that such cases revolve in an arena of societal illegitimacy: an illegitimacy that exists where the effects of state-fueled discrimination persist in a society committed to equal justice under law. From this perspective, analysis of judicial legitimacy gains a clearer focus: The task becomes not simply to count flaws in specific judicial proposals, but to ask what is the most legitimate-or least detrimental-role ${ }^{\mathbf{1 0 7}}$ for our judiciary to play in confronting this pre-existing societal dilemma.

\section{CONCLUSION}

In 1883, the political realities that had inspired both the Givil War Amendments and the legislative efforts to assist the freed slaves took a turn for the worse. The 1875 Civil Rights Act had lost popular support, and in the Civil Rights Cases ${ }^{108}$ of 1883, the Supreme Court overturned the Act, claiming Congress lacked the power to outlaw racial discrimination in public accommodations. Shortly after the decision, Frederick Douglass said at a Civil Rights Mass-Meeting:

It is said that this decision will make no difference in the treatment of colored people; that the Givil Rights Bill was a dead letter, and could not be enforced. There is some truth in all this, but it is not the whole truth. That bill, like all advanced legislation, was a banner on the outer wall of American liberty, a noble moral standard, uplifted for the education of the American people. There are tongues in trees, books, in the running brooks, - - sermons in stones. This law, though dead, did speak. It expressed the sentiment of justice and fair play, common to every honest heart. Its voice was against popular prejudice and meanness. . . . It told the American people that they were all equal before the law; that they belonged to a common country and were equal citizens. The Supreme Court has hauled down this flag of liberty in open day . ... . It is a concession to race pride, selfishness and meanness, and will be received with joy by every upholder of caste in the land, and for this I deplore and denounce that decision. ${ }^{109}$

resistance at the right-declaring stage as part of the cluster of factors that influence . . . rights").

107. This term is borrowed from J. Golnstein, A. Freun \& P. Solnit, Beyond tHE Best INTERESTS OF THE CHILD 6 (1973). The authors favor this term in cases of child abuse so that the decisionmaker fully appreciates that he or she is confronting an unavoidably negative situation. Id. at 53-64. The advantage of this perspective for judicial review of entrenched discrimination is to deter the rejection of judicial policies because they are imperfect instead of because a less detrimental theory exists.

108. 109 U.S. 3 (1883).

109. 4 P. Foner, The Life and Writings of Frederick Douglass 401 (1955). Compare 
Thirteen years later, the moral and constitutional standard for equality for over a half-century was set in Plessy $v$. Ferguson. ${ }^{110}$

-Gene B. Sperling

with Giles v. Harris, 189 U.S. 475, 488 (1902) (Holmes, J.) (in case involving attempt of Alabama state legislature to disenfranchise black voters, jurisdiction refused because "the great mass of the white population intends to keep the blacks from voting ... [and] . . . a name on a piece of paper will not defeat them . . . . [R]elief from a great political wrong, if done, as alleged, by the people of a state and the State itself, must be given by them or by the legislative and political department of the government of the United States."). See supra note 75.

110. See G. MYRDAL, supra note 43, at 30, 46 (1944):

[I]t was a not unusual experience of the writer to be told . . by the learned . . . [and] . . .

by the laity, that there is 'no Negro problem' in America..... In the big cities where the greater part of the total Northern Negro population lives, the whites are protected from getting the Negro problem too much on their minds by ... the spatial segregation of racial, ethnic, and economic groups....

See Herbers, Census Data Reveal 70's Legacy: Poorer Cities and Richer Suburbs, N.Y. Times, Feb. 27,1983 , at 1, col. 2 (U.S. Gensus show inner cities becoming increasingly poor and increasingly concentrated with minorities); Rohatyn, Catching Up, N.Y. Times, Jan. 20, 1985, at E5, col. 5 ("Clearly, you have to try to break down the ghetto structure .... [and the] racial aspects to these problems. . . . You know, everybody talked about city problems 10 years ago. Today you never hear it. It's as if they didn't exist anymore."). 